\title{
Internalization and cytotoxicity are important virulence mechanisms in vibrio-fish epithelial cell interactions
}

\author{
X. H. Wang, ${ }^{1}$ H. L. Oon, ${ }^{1}$ G. W. P. Ho, ${ }^{1}$ W. S. F. Wong, ${ }^{2}$ T. M. Lim ${ }^{1}$ \\ and $\mathrm{K}$. Y. Leung ${ }^{1}$
}

Author for correspondence: K. Y. Leung. Tel: +65 8747835. Fax: +65 7792486.

e-mail: dbslky@nus.edu.sg

Department of Biological Sciences, Faculty of Science 1 , and Department of Pharmacology, Faculty of Medicine2, National University of Singapore, 10 Kent Ridge Crescent, Singapore 119260
Vibrio anguillarum and Vibrio damselae are Gram-negative bacteria that cause systemic infections called vibriosis in fish. They can enter fish cells and survive as intracellular parasites. The host-pathogen interactions between these Vibrio species and the fish epithelial cell lines epithelioma papillosum of carp (EPC) and grunt-fin tissue (GF) cells, were examined using phase-contrast, scanning electron and confocal microscopy. In addition, potential signal transduction pathways that precede bacterial internalization were studied by using signal transduction inhibitors. Some Vibrio species induced morphological changes in fish cells and this allowed classification into a cytopathic group and a noncytopathic group. The cytopathic group could be subdivided into two invasive groups (I and II) and a cytotoxic group. Of the invasive strains $V$. anguillarum 811218-5W (group I) and G/Nirus/5(3) (group II), genistein, a tyrosine kinase inhibitor, only inhibited internalization of $V$. anguillarum G/Virus/5(3) into EPC cells, whereas staurosporine, a protein kinase $C$ inhibitor, accelerated internalization of both strains. Cytochalasin D, an inhibitor of microfilament polymerization, prevented internalization of both strains, whilst vincristin, a microtubule inhibitor, only inhibited internalization of $\boldsymbol{V}$. anguillarum G/Virus/5(3). For the cytotoxic strain V. damselae ATCC 33539, extracellular products (ECP) alone caused morphological changes in EPC and GF. Bacterial internalization may not be important in the pathogenesis of this group. The non-cytopathic strain V. anguillarum S2/5/93(2) did not enter cells or induce any changes in EPC and GF monolayers. This study has identified some major differences between Vibrio species in their interactions with fish cells in vitro and will thus facilitate future studies of the molecular basis of pathogenesis of vibriosis.

Keywords: vibrios, adhesion, internalization, signal transduction

\section{INTRODUCTION}

Vibrio species are an emerging group of fish pathogens that has seriously affected the marine and fresh water aquacultural industry worldwide (Austin \& Austin, 1993; Breed, 1996). Outbreaks of vibriosis usually occur only when fish are immunocompromised or under stress due to overcrowding (Thune et al., 1993). Vibriosis generally manifests as a haemorrhagic septicaemia with

Abbreviations: BAPTAAM, 1,2-bis(o-aminophenoxy)ethane- $N, N, N^{\prime}, N^{\prime}-$ tetraacetic acid tetra(acetoxymethyl ester); ECP, extracellular products; EPC, epithelioma papillosum of carp; GF, grunt-fin tissue. extensive skin lesions and focal necrosis of the liver, spleen, kidney and other tissues (Hjeltnes \& Roberts, 1993; Thune et al., 1993). Many factors have been implicated in the pathogenesis of vibriosis in fish. These include the production of haemolysins (Munn, 1978; Toranzo \& Barja, 1993), proteases (Norqvist et al., 1990), a capsule (Yoshida et al., 1985; Wright et al., 1990), iron-binding proteins (Actis et al., 1985) and the presence of a $40 \mathrm{kDa}$ hydrophobic surface antigen, VSP1 (Espelid et al., 1987).

It has been postulated that the portals of entry for Vibrio species into fish are the gastrointestinal tract (Horne \& Baxendale, 1983; Kanno et al., 1989; Olsson et al., 
1996), gills (Baudin-Laurencin \& German, 1987) and the skin (Grimes et al., 1985; Kanno et al., 1989). It is necessary for the vibrios to penetrate through the epithelial cells to gain access into the host before spreading systemically. For many bacterial pathogens, entry into non-phagocytic cells involves triggering host signal transduction mechanisms to induce rearrangement of the host cytoskeleton, thereby facilitating bacterial uptake (Rosenshine \& Finlay, 1993; Finlay \& Cossart, 1997; Finlay \& Falkow, 1997). The ability to invade epithelial cells is a common virulence character in various pathogenic bacteria, including Aeromonas bydrophila in fish (Leung et al., 1996; Tan et al., 1998) and human pathogens such as enteropathogenic Escherichia coli (Donnenberg et al., 1989, 1990; Rosenshine et al., 1996), Salmonella (Finlay \& Falkow, 1989; Finlay et al., 1992) and Yersinia species (Finlay \& Falkow, 1988; Miller et al., 1988).

The interactions between the host and Vibrio species have not been extensively investigated. In this work, we aimed to examine the interaction between vibrios and fish epithelial cells. Phase-contrast, confocal and scanning electron microscopy, and adhesion and invasion assays were used to elucidate the intimate vibrio-host interactions. In addition, inhibitors that interrupt cytoskeleton or signal transduction pathways were used to examine the process of internalization of vibrios. All of these studies may provide some clues as to how fish pathogens enter non-phagocytic cells and initiate infections in the host.

\section{METHODS}

Bacterial strains and media. The 24 strains of vibrios examined and their sources are given in Table 1 . All were fish isolates. Four strains were chosen for detailed study, Vibrio anguillarum G/Virus/5(3), S2/5/93(2), 811218-5W and Vibrio damselae (previously Vibrio damsela) ATCC 33539. These strains were tested using standard biochemical diagnostic kits (Microbact Identification Kit 24E from DP Diagnostics and BBL Crystal Enteric/Nonfermenter ID System from Becton Dickinson), and their identities were further confirmed according to the criteria of Breed (1996) and Hjeltnes \& Roberts (1993). Cultures were routinely grown in tryptic soy agar (TSA; Difco) or tryptic soy broth (TSB; Difco) supplemented with $0.5 \% \mathrm{NaCl}$ at $25^{\circ} \mathrm{C}$. Stock cultures were maintained at $-80^{\circ} \mathrm{C}$ as a suspension in supplemented TSB containing $25 \%(\mathrm{v} / \mathrm{v})$ glycerol.

Protease and haemolysin production were determined using brain heart infusion skim milk agar (BHISMA; Difco) plates and $5 \%$ heparinized tilapia whole blood in TSA medium, respectively. The amounts of protease and haemolysin produced were estimated from the diameter of the clear zones after $72 \mathrm{~h}$ incubation.

Serum resistance assay. Blood was collected from the caudal vein of naive tilapia and serum separated from the clot by centrifugation at $4^{\circ} \mathrm{C}$. Bacteria grown in TSB at $25^{\circ} \mathrm{C}$ for $24 \mathrm{~h}$ were collected by centrifugation and washed three times with PBS (137 mM NaCl, $2.7 \mathrm{mM} \mathrm{KCl,} 4.3 \mathrm{mM} \mathrm{Na}_{2} \mathrm{HPO}_{4}, 1.4 \mathrm{mM}$ $\mathrm{KH}_{2} \mathrm{PO}_{4}, \mathrm{pH} 7 \cdot 2$ ). The cell suspension was mixed with tilapia serum to give a final serum concentration of $50 \%$ and the bacterial count was adjusted to about $5 \times 10^{7}$ c.f.u. Tubes were incubated at $25^{\circ} \mathrm{C}$ and samples were removed at $1 \mathrm{~h}$ for serial dilutions and plate counts on TSA. Survival was calculated by dividing the number of viable bacteria after serum treatment by the number of viable bacteria before treatment, as described previously (Leung et al., 1995). A value greater than one was scored as serum-resistant, while a value below one was scored as serum-sensitive. The data were obtained from three independent experiments.

$\mathbf{L D}_{50}$ determinations. Naive blue gourami, Trichogaster trichopterus (Pallas) weighing approximately $15 \mathrm{~g}$ were maintained in well aerated water at $25-28^{\circ} \mathrm{C}$ and fed commercial pellets at $1 \%$ body weight per day. Fish were anaesthesized for handling in water containing $0.02 \%(\mathrm{v} / \mathrm{v}) 2$-phenoxyethanol (Sigma). For $50 \%$ lethal dose $\left(\mathrm{LD}_{50}\right)$ determinations, three groups of six fish were each injected intraperitoneally with $0 \cdot 1 \mathrm{ml}$ PBS-washed bacterial cells adjusted to the required concentrations. Fish were monitored for $7 \mathrm{~d}$. The $\mathrm{LD}_{50}$ values were calculated by the method of Reed \& Muench (1938).

Cell culture. All tissue culture reagents were obtained from Gibco. Epithelioma papillosum of carp (Cyprinus carpio) (EPC) (Wolf \& Mann, 1980) and grunt-fin (Haemulon sciurus) tissue (GF) cells (Clem et al., 1961) were grown in minimal essential medium (MEM) with Hanks' balanced salts solution (Sigma), $10 \mathrm{mM}$ HEPES (pH 7.3), $2 \mathrm{mM}$ glutamine, $0.23 \%$ $\mathrm{NaHCO}_{3}$ and $10 \%(\mathrm{v} / \mathrm{v})$ heat-inactivated foetal bovine serum at $25^{\circ} \mathrm{C}$ in a $5 \%(\mathrm{v} / \mathrm{v}) \mathrm{CO}_{2}$ atmosphere. For culturing GF, MEM was supplemented with $58 \mathrm{mM} \mathrm{NaCl}$ for optimal growth. Cells were grown in $75 \mathrm{ml}$ flasks and divided at least once a week by trypsin/EDTA treatment and dilution at $1: 10$ in fresh media.

Cytoskeleton and signal transduction inhibitors. Inhibitors and their concentrations used are listed in Table 3. DMSO was used to dissolve all chemicals. Prior to use, the inhibitors were further diluted in MEM supplemented with $10 \%$ foetal bovine serum and added to the cultured fish cells.

Morphological changes in fish epithelial cells induced by Vibrio species. Studies on morphological changes were conducted by seeding $5 \times 10^{5}$ cultured fish cells into each well of a 24-well tissue culture plate (Falcon) and were performed as described by Leung $e t$ al. (1996). Briefly, $5 \mathrm{ml}$ stationary-phase cultures were prepared by inoculating supplemented TSB with vibrios from frozen glycerol stocks and incubating overnight at $25^{\circ} \mathrm{C}$. Three hours prior to infection of cells, midexponential-phase cultures were prepared by diluting the overnight culture 1:20 in fresh supplemented TSB and incubating at $25^{\circ} \mathrm{C}$ for $2.5 \mathrm{~h}$. Bacterial cells were pelleted and washed three times in PBS before adding $5 \mu$ lo each tissue culture well (approximately $5 \times 10^{5}$ bacteria). After inoculation, the 24-well tissue culture plate was centrifuged $(800 \mathrm{~g}$, $5 \mathrm{~min}, 4^{\circ} \mathrm{C}$ ), then incubated at $25^{\circ} \mathrm{C}$. The morphology of fish cells was examined using an Axiovert $25 \mathrm{CFL}$ phase-contrast inverted microscope (Carl Zeiss) at $\times 200$ magnification.

Morphological changes in fish epithelial cells induced by extracellular products (ECP) of vibrios. ECP produced on BHISMA plates were prepared as described by Leung \& Stevenson (1988). Sterilized dialysis membranes with a molecular mass exclusion size of 12000-14000 Da (Sigma) were placed on the surface of BHISMA plates supplemented with $0.5 \%(\mathrm{w} / \mathrm{v}) \mathrm{NaCl}$. An overnight bacterial culture was inoculated and spread on the dialysis membrane. After $24 \mathrm{~h}$ at $25^{\circ} \mathrm{C}$, the cells were washed from the membrane with $3 \mathrm{ml}$ PBS. ECP were prepared by centrifugation of the cell suspension for $15 \mathrm{~min}$ at $5600 \mathrm{~g}$ at $4^{\circ} \mathrm{C}$ and the supernatant was filtered through a $0.22 \mu \mathrm{m}$ filter. Bacterial numbers were quantified by plate counts on TSA. ECP derived from approximately $5 \times 10^{5}-5 \times 10^{7}$ bacteria were added to each 
Table 1. Group, source and virulence characteristics of Vibrio strains

\begin{tabular}{|c|c|c|c|c|c|c|}
\hline Group ${ }^{*}$ & Strain & Source $†$ & Protease $\neq$ & Haemolysin $\ddagger$ & $\begin{array}{c}\text { Serum } \\
\text { resistance } \$\end{array}$ & $\mathrm{LD}_{50} \|$ \\
\hline \multicolumn{7}{|l|}{ Cytopathic } \\
\hline \multirow[t]{6}{*}{ Invasive I } & V. anguillarum $811218-5 \mathrm{~W}$ & NTU, Taiwan & + & + & $0 \cdot 35 \pm 0 \cdot 11$ & $10^{6 \cdot 8}$ \\
\hline & V. vulnificus ATCC 33149 & Japan & - & + & $7 \cdot 34 \pm 1 \cdot 39$ & $10^{4 \cdot 4}$ \\
\hline & V. vulnificus ATCC 33147 & Japan & - & + & $5 \cdot 40 \pm 1 \cdot 80$ & $10^{4 \cdot 3}$ \\
\hline & V. vulnificus ATCC 33148 & Japan & - & + & $1.49 \pm 0.30$ & $10^{5 \cdot 3}$ \\
\hline & V. harveyi W618 & PPD, Singapore & - & - & $1 \cdot 37 \pm 0 \cdot 27$ & $10^{3 \cdot 9}$ \\
\hline & V. vulnificus $\mathrm{S} 1 / 7 / 93(1)$ & PPD, Singapore & - & + & $1 \cdot 43 \pm 0.46$ & $10^{3 \cdot 3}$ \\
\hline \multirow[t]{7}{*}{ Invasive II } & V. damselae $\mathrm{E} 311$ & Hubei, China & + & + & $0.62 \pm 0.06$ & $10^{6 \cdot 9}$ \\
\hline & V. anguillarum $\mathrm{G} /$ Virus $/ 5(3)$ & PPD, Singapore & - & - & $3 \cdot 99 \pm 1 \cdot 30$ & $10^{5 \cdot 8}$ \\
\hline & $V$. anguillarum $01 / 10 / 93(2)$ & PPD, Singa pore & - & + & $1 \cdot 51 \pm 0.35$ & $10^{5 \cdot 1}$ \\
\hline & V. harveyi $\mathrm{S} 1 / 5 / 93(4)$ & PPD, Singapore & - & + & $9 \cdot 76 \pm 1.07$ & $10^{5 \cdot 4}$ \\
\hline & V. parahaemolyticus W368-1p & PPD, Singapore & - & + & $2 \cdot 11 \pm 0 \cdot 68$ & $10^{5 \cdot 4}$ \\
\hline & $V$. alginolyticus $240 / 89$ & PPD, Singapore & + & + & $1 \cdot 64 \pm 0.39$ & $10^{5 \cdot 5}$ \\
\hline & V. vulnificus S1/4/93(4) & PPD, Singapore & - & + & $1 \cdot 36 \pm 0.23$ & $10^{5 \cdot 5}$ \\
\hline \multirow[t]{2}{*}{ Cytotoxic } & V. damselae ATCC 33539 & California, USA & - & + & $1 \cdot 79 \pm 0 \cdot 14$ & $10^{2 \cdot 6}$ \\
\hline & V. damselae 6/95(S1) & PPD, Singapore & - & + & $4 \cdot 33 \pm 0 \cdot 40$ & $10^{7 \cdot 0}$ \\
\hline \multirow{9}{*}{$\begin{array}{l}\text { Non- } \\
\text { cytopathic }\end{array}$} & V. anguillarum NIE275 & NTU, Taiwan & + & + & $0 \cdot 55 \pm 0 \cdot 12$ & $10^{6 \cdot 2}$ \\
\hline & V. anguillarum A194-168 & Alabama, USA & - & + & $2 \cdot 36 \pm 0 \cdot 68$ & $>10^{7 \cdot 3}$ \\
\hline & V. anguillarum $\mathrm{L} 1$ & Bangalore, India & + & + & $0 \cdot 37 \pm 0 \cdot 10$ & $>10^{7 \cdot 7}$ \\
\hline & V. anguillarum $\mathrm{F} 1$ & Bangalore, India & - & + & $1 \cdot 36 \pm 0.06$ & $>10^{7 \cdot 7}$ \\
\hline & V. anguillarum $\mathrm{F} 3$ & Bangalore, India & - & + & $0 \cdot 47 \pm 0 \cdot 13$ & $>10^{8 \cdot 0}$ \\
\hline & V. ordalii ATCC 33509 & Washington, USA & + & - & $0.55 \pm 0.13$ & $>10^{7 \cdot 9}$ \\
\hline & V. anguillarum ATCC 14181 & Unknown & + & + & $0 \cdot 31 \pm 0 \cdot 14$ & $10^{6 \cdot 1}$ \\
\hline & V. anguillarum ATCC 68554 & Unknown & + & - & $0 \cdot 66 \pm 0 \cdot 17$ & $10^{7 \cdot 0}$ \\
\hline & $V$. anguillarum S2/5/93(2) & PPD, Singapore & - & + & $0.15 \pm 0.03$ & $10^{6 \cdot 6}$ \\
\hline
\end{tabular}

* Based on the morphological changes in EPC and GF cells as described in the Results. Data were obtained from three independent experiments.

†NTU, National Taiwan University; PPD, Primary Production Department.

¥For the detection of proteases and haemolysins, Vibrio cultures were grown overnight in TSB supplemented with $0.5 \% \mathrm{NaCl}$ at $25{ }^{\circ} \mathrm{C}$. Overnight cultures were inoculated onto BHISMA, and TSA with $5 \%(\mathrm{v} / \mathrm{v}$ ) tilapia whole blood for the detection of proteases and haemolysins, respectively. The production of exoenzymes was measured by the diameter of the hydrolytic zones. Data were obtained from three independent experiments.

SSurvival in serum was calculated by dividing the viable bacterial population after serum treatment by the initial population before serum treatment. A value greater than one was scored as serum-resistant, whilst a value below one was scored as serum-sensitive. Data were obtained from three independent experiments.

$\| \mathrm{LD}_{50}$ values were calculated by the method of Reed \& Muench (1938).

well of a 24-well culture plate containing fish epithelial cells. The plates were then incubated at $25^{\circ} \mathrm{C}$.

ECP were also produced in tissue culture. Cultured fish cells in 24-well tissue culture plates were inoculated with different Vibrio strains and incubated for $3 \mathrm{~h}$. MEM in the wells was then removed and filtered through a $0.22 \mu \mathrm{m}$ filter. A $0.5 \mathrm{ml}$ sample of MEM containing ECP was added to each well of a 24-well tissue culture plate containing fish epithelial cells. Fish cell morphology was examined using an Axiovert $25 \mathrm{CFL}$ phase-contrast inverted microscope (Carl-Zeiss) at $\times 200$ magnification. The effect of ECP was determined from two wells in triplicate experiments

Adhesion and invasion assays. The adhesion and invasion assays were performed as described previously with minor modifications (Leung \& Finlay, 1991; Elsinghorst, 1994).
Briefly, monolayers of EPC cells were grown for $72 \mathrm{~h}$ in 24well tissue culture plates to $100 \%$ confluence. The cells were then washed with MEM and incubated with the respective inhibitors at $25^{\circ} \mathrm{C}$ for $30 \mathrm{~min}$ before inoculation of bacteria. The inoculated plates were centrifuged for $5 \mathrm{~min}$ at $800 \mathrm{~g}$ at $4^{\circ} \mathrm{C}$ and then incubated for a further $30 \mathrm{~min}$ at $25^{\circ} \mathrm{C}$. To measure the number of bacteria adhering to the monolayers, the plates were washed six times with Hanks' salts, the EPC cells lysed with $1 \%(\mathrm{v} / \mathrm{v})$ Triton $\mathrm{X}-100$ in PBS, and then bacterial numbers quantified by plate counting (Elsinghorst, 1994). To measure invasion, monolayers were washed three times with Hanks' salts, then incubated for an additional $2 \mathrm{~h}$ in tissue culture medium containing $100 \mu \mathrm{g}$ gentamicin (Sigma) $\mathrm{ml}^{-1}$ to kill extracellular bacteria. After incubation, the monolayers were washed twice with Hanks' salts solution, the EPC cells lysed with $1 \%$ Triton X-100 in PBS and bacterial 

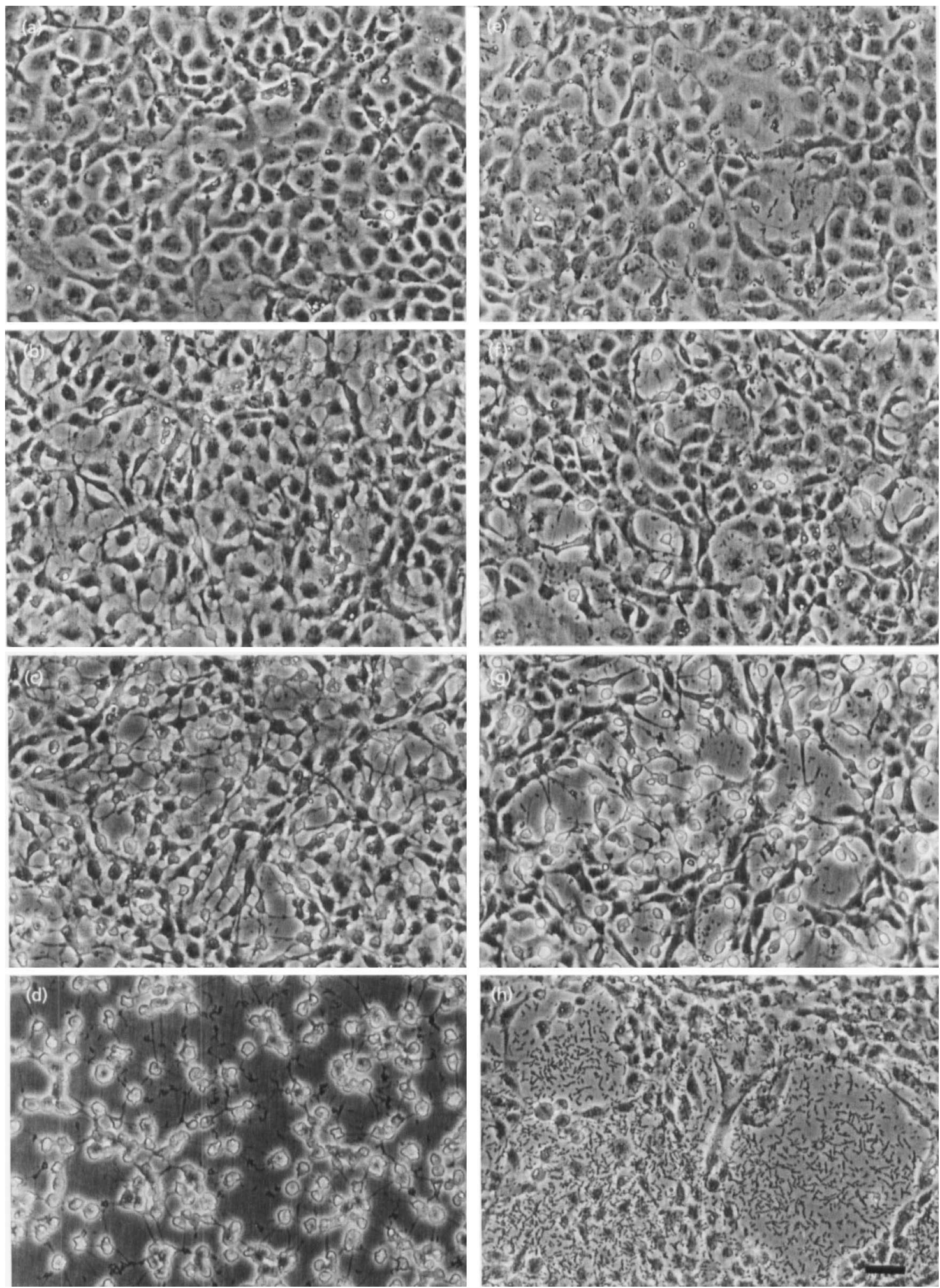

Fig. 1. Phase-contrast micrographs of EPC cells infected with different Vibrio strains. (a) Uninfected control. (b) Stage $\mid$ of infection (40 min), (c) stage II of infection (47 min) and (d) stage III of infection (90 min) with V. anguillarum 811218-5W. (e) EPC monolayer infected with avirulent $V$. anguillarum S2/5/93(2) strain for $2 \mathrm{~h}$. (f) Stage I of infection (70 min) and (g) stage II of infection (120 min) with V. anguillarum GNirus/5(3). (h) EPC cells infected with V. damselae ATCC 33539 for 75 min. Bar, $25 \mu \mathrm{m}$. 

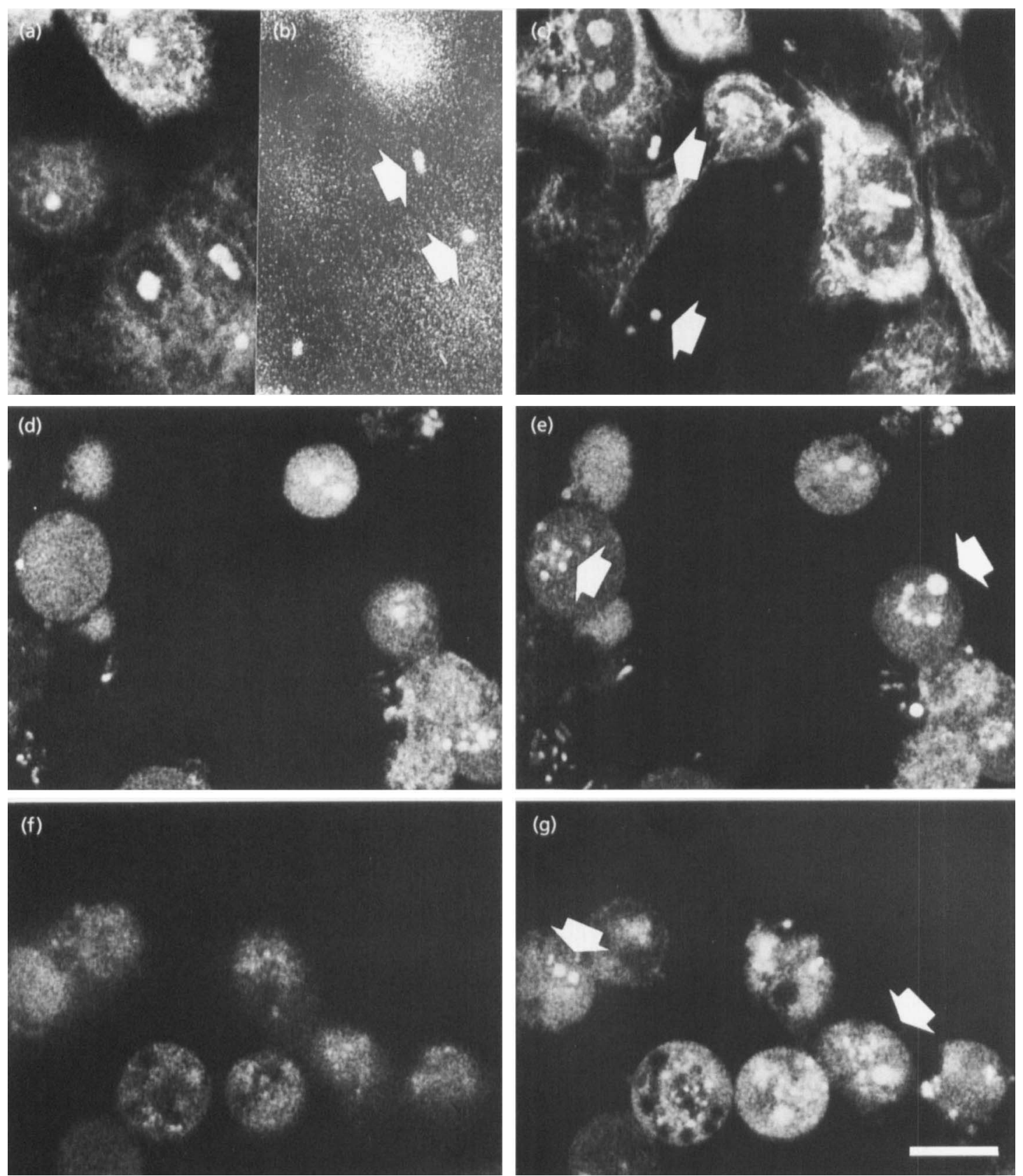

Fig. 2. Confocal micrographs of EPC cells infected with different Vibrio strains. (a, b) Infection with avirulent $V$. anguillarum S2/5/93(2) strain for $3 \mathrm{~h}$. Monolayers of EPC cells remained intact at the bottom of the culture (a) and bacteria were seen on top of the monolayer (b). (c) Infection with $V$. damselae ATCC 33539 for $3 \mathrm{~h}$. Bacteria were seen outside the cells (indicated by arrows). (d, e, $f, g)$ Confocal optical sections of EPC cells infected with $V$. anguillarum 811218-5W (d, e) and with G/Virus/5(3) ( $f, g)$. The bacterial cells were labelled with Live/Dead BacLight Viability Kit before infection. Two optical sections were taken, starting with the apical region of the cell (d) and ( $f$ ) and moving $2 \mu \mathrm{m}$ downward towards the basal surface $(e, g)$. The intracellular bacteria, indicated by arrows, appeared after the $2 \mu \mathrm{m}$ sectioning. Bar, $10 \mu \mathrm{m}$.

numbers quantified by plate counting. The adhesion and invasion rates were calculated from the mean of at least two wells in quadruple experiments.

In studies of the adhesion ability of vibrios on plastic coverslips, washed bacteria were placed on Thermanox coverslips (Nunc) in 24-well tissue culture plates and the plates were centrifuged as described above. They were then incu- bated in a $25^{\circ} \mathrm{C}$ carbon dioxide incubator for $1 \mathrm{~h}$. The coverslips were then rinsed twice with PBS and prepared for scanning electron microscopy as described below. In studies of different signal transduction inhibitors, EPC cells were incubated with each of the inhibitors for $30 \mathrm{~min}$ prior to inoculation with bacteria.

To ensure that EPC cells were not affected by the inhibitors, 
Table 2. Proportion of adherent and intracellular Vibrio species in EPC cell cultures

Values were recorded as means \pm SEM for four trials, each in triplicate. Within each column, values followed by different superscript letters are significantly different $(P<0 \cdot 05)$.

\begin{tabular}{|c|c|c|c|c|}
\hline Group & Strain & Inoculum $\left(\times 10^{5}\right)$ & Adherence $(\%)^{*}$ & Invasion $(\%) \dagger$ \\
\hline \multicolumn{5}{|l|}{ Cytopathic } \\
\hline Invasive I & V. anguillarum $811218-5 \mathrm{~W}$ & $\begin{array}{c}28 \pm 3 \\
4.7 \pm 1.0\end{array}$ & $\begin{array}{l}75 \cdot 8 \pm 6 \cdot 5^{a} \\
88 \cdot 6 \pm 3 \cdot 5^{a}\end{array}$ & $\begin{array}{l}3.5 \pm 0.7^{d} \\
2.8 \pm 0.6^{d}\end{array}$ \\
\hline Invasive II & V. anguillarum G/Virus/5(3) & $8.6 \pm 0.9$ & $17 \cdot 2 \pm 1 \cdot 7^{a}$ & $2 \cdot 1 \pm 0 \cdot 5^{d}$ \\
\hline & & $2 \cdot 4 \pm 0.6$ & $28 \cdot 6 \pm 4 \cdot 0^{a}$ & $1 \cdot 5 \pm 0 \cdot 2^{d}$ \\
\hline Cytotoxic & V. damselae ATCC 33539 & $\begin{array}{l}11 \pm 1 \\
3 \cdot 2 \pm 1 \cdot 1\end{array}$ & $\begin{array}{l}2 \cdot 7 \pm 0 \cdot 6^{b} \\
2 \cdot 4 \pm 0 \cdot 5^{b}\end{array}$ & $\begin{array}{l}0.09 \pm 0.04^{e} \\
0.15 \pm 0.07^{e}\end{array}$ \\
\hline Non-cytopathic & V. anguillarum $S 2 / 5 / 93(2)$ & $\begin{array}{l}9.4 \pm 2.2 \\
3.7 \pm 0.7\end{array}$ & $\begin{array}{r}6 \cdot 1 \pm 1 \cdot 7^{c} \\
10 \cdot 0 \pm 2 \cdot 0^{c}\end{array}$ & $\begin{array}{l}0.83 \pm 0.10^{f} \\
0.85 \pm 0.08^{f}\end{array}$ \\
\hline
\end{tabular}

* Adherence is expressed as percentage of bacteria still adherent after washing without gentamicin treatment $(n=4)$.

† Invasion is expressed as percentage of input bacteria surviving after gentamicin treatment for $2 \mathrm{~h}(n=4)$.

they were grown for $2 \mathrm{~h}$ in MEM containing each of the inhibitors, DMSO $(0.4 \%)$, or calcium- and serum-free MEM. A trypan blue exclusion assay was performed to determine whether treated EPC cells had viabilities similar to the untreated control. Similarly, Vibrio species were treated with each of these inhibitors for $2 \mathrm{~h}$. Bacterial viability counts were determined after $2 \mathrm{~h}$ incubation. Viabilities of EPC and bacteria were expressed as a percentage of untreated controls and were determined in triplicate experiments.

Confocal microscopy. The Live/Dead BacLight Viability Kit (Molecular Probes) was used to fluorescently label bacteria according to the manufacturer's instructions. Briefly, fresh cultures of bacteria were washed three times in PBS and then stained for $15 \mathrm{~min}$ in the dark. Fish cells were seeded on glass coverslips in a 24-well tissue culture plate and inoculated with vibrios as described above. At appropriate time intervals, the coverslips were removed and examined using a Nikon Optiphot microscope attached to the Bio-Rad MRC 500 confocal system (Lasersharp). Confocal images obtained under the argon laser ( $488 \mathrm{~nm}$ blue excitation) at $\times 600$ were photographed with a Polaroid Freeze-frame recorder using Kodak Tmax 100 film.

Scanning electron microscopy. Thermanox coverslips with vibrios alone, Vibrio-infected and uninfected fish cells were fixed with $2 \%(\mathrm{v} / \mathrm{v})$ glutaraldehyde and $2 \%(\mathrm{v} / \mathrm{v})$ formaldehyde in PBS for $3 \mathrm{~h}$ at $4{ }^{\circ} \mathrm{C}$. After washing three times with PBS, $4 \%(\mathrm{v} / \mathrm{v})$ osmium tetroxide was added to each well for $1 \mathrm{~h}$ at $4{ }^{\circ} \mathrm{C}$. After dehydration in a graded series of ethanol dilutions, cells were subjected to critical point drying with $\mathrm{CO}_{2}$ (Samdri-780A, Tousimis Research Corporation). Samples were covered with gold in a gold ion sputter (JFC1100 Ion Sputter, JEOL) and examined under a scanning transmission electron microscope (JEM-100 CXII electron microscope with ASID attachment, JEOL) at an accelerating voltage of $60 \mathrm{kV}$. Photographs were taken with Agfa APX 100 black and white film.

Statistical analysis. All data from morphological and invasion assays were expressed as means $\pm S E M$. The data were analysed using one-way ANOVA and a Duncan multiple range test (SAS software, SAS Institute). Values of $P<0.05$ were considered significant.

\section{RESULTS}

\section{Morphological changes induced in EPC cells by vibrios are correlated with virulence}

Twenty-four Vibrio strains were tested for their production of haemolysins and proteases, serum resistance, the induction of cytopathic changes in EPC and GF cells and their $\mathrm{LD}_{50}$ values in blue gourami. Table 1 shows that vibrios that cause cytopathic changes in EPC and GF cells have lower $L_{50}$ values $\left(<10^{6}\right)$, except $V$. anguillarum 811218-5W, and V. damselae E311 and $6 / 95(\mathrm{~S} 1)$. On the other hand, there is no clear indication that serum resistance and the production of protease and haemolysin are linked with lower $L_{50}$ values $\left(<10^{6}\right)$ in vibrios. Based on the examinations of the morphological changes in Vibrio-infected fish cells under phase-contrast microscopy at $8 \mathrm{~h}$ post-inoculation $(n=3)$, the strains could be classified into two main groups, namely the cytopathic group and the noncytopathic group (Table 1). Members of the cytopathic group induced morphological changes in EPC and GF monolayers whereas members of the non-cytopathic group had not induced any changes in the monolayers by $8 \mathrm{~h}$ post-inoculation. The cytopathic group could be further subdivided into invasive groups I and II, and a cytotoxic group (Table 1). Fish cells infected with members of invasive group I underwent two (for GF cells) or three (for EPC cells) distinct stages of morphological changes. The host cells initially formed pointed ends or edges, then gradually changed from a tight network of abutting cells to a loose connection. Eventually the host cells became rounded and appeared transparent. With members of invasive group II, stages of morphological changes were less clear. A small percentage of rounded and transparent host cells were observed soon after infection and the abundance of such transparent cells increased gradually over time. With the cytotoxic group, infected host cells became detached from each other and also from the well. Gaps appeared 

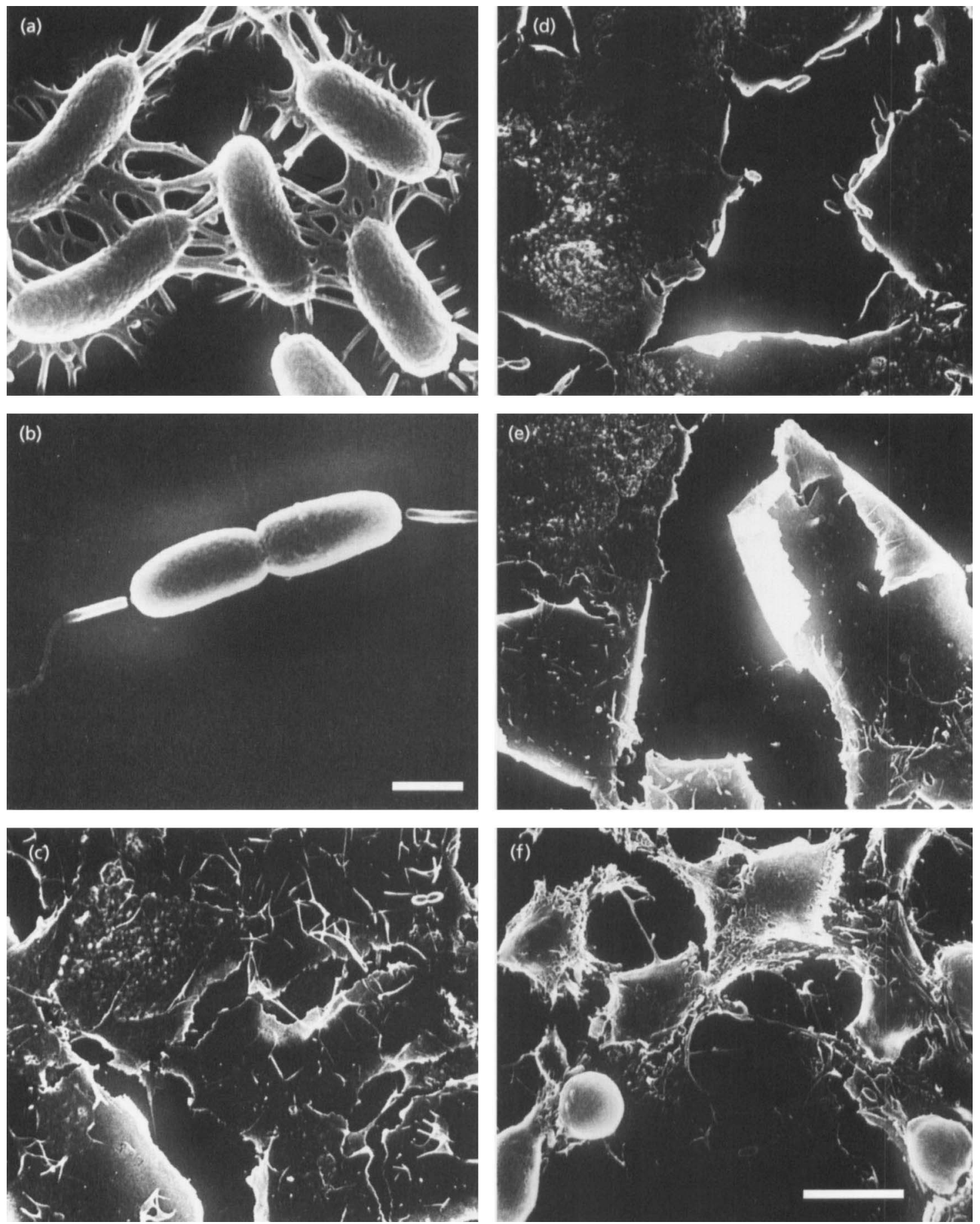

Fig. 3. Scanning electron micrographs of vibrios and infected EPC monolayers. (a) $V$. anguillarum 811218-5W on the coverslip after incubation for $60 \mathrm{~min}$, showing appendages of the bacteria joining to form a network. (b) $V$. anguillarum GNirus/5(3) on the coverslip. (c) Infection of EPC cells with $V$. anguillarum S2/5/93(2). Cell morphology was similar to that of the control group. (d) Infection of EPC cells with cytotoxic V. damselae ATCC 33539 strain for $1 \mathrm{~h}$. The edges of the cells folded upwards and the microvilli were not visible. The monolayer also appeared to be loosely attached to the surface. (e) Three hours after inoculation, there was a greater folding of the cells. (f) EPC cells infected with $V$. anguillarum GNirus/5(3). Ninety minutes after inoculation the cell morphology had changed dramatically. The cells became condensed and retracted into ball-like structures. There were also some cells that were in stages I and II of infection, as seen in Fig. 5. Bar in (b) (also applies to a), $1 \mu \mathrm{m}$; bar in (f) (also applies to c-e), $15 \mu \mathrm{m}$. 
Table 3. Effect of inhibitors of bacterial invasion on internalization of Vibrio species by EPC cells

Values represent the ratio of gentamicin-resistant bacteria in the presence of inhibitor to gentamicin-resistant bacteria without inhibitor and are expressed as percentages (mean $\pm \operatorname{SEM} ; n=4$ ). Values followed by an asterisk are significantly different from the untreated control $(P<0.05)$.

\begin{tabular}{|c|c|c|c|}
\hline Inhibitor & Class & $\begin{array}{c}\text { V. anguillarum } \\
811218-5 \mathrm{~W} \\
\text { (invasive group I) }\end{array}$ & $\begin{array}{c}\text { V. anguillarum } \\
\text { G/Virus/5(3) } \\
\text { (invasive group II) }\end{array}$ \\
\hline None & Control & 100 & 100 \\
\hline DMSO $(0 \cdot 4 \%)$ & Solvent & $103 \cdot 9 \pm 15 \cdot 9$ & $76 \cdot 6 \pm 37 \cdot 3$ \\
\hline Genistein $(150 \mu \mathrm{M})$ & Protein tyrosine kinase inhibitor & $95 \cdot 5 \pm 12 \cdot 1$ & $48 \cdot 6 \pm 10 \cdot 6^{*}$ \\
\hline PD098059 $(20 \mu \mathrm{M})$ & MAPK kinase inhibitor & $105 \cdot 5 \pm 9 \cdot 3$ & $89 \cdot 9 \pm 7 \cdot 8$ \\
\hline BAPTA/AM $(50 \mu \mathrm{M})$ & Intracellular $\mathrm{Ca}^{2+}$ chelator & $103 \cdot 0 \pm 10 \cdot 6$ & $45 \cdot 2 \pm 7 \cdot 5^{*}$ \\
\hline MEM without $\mathrm{Ca}^{2+}$ and serum & Medium control & $101 \cdot 8 \pm 4 \cdot 2$ & $95.8 \pm 8.9$ \\
\hline Cytochalasin D $\left(0 \cdot 1 \mu \mathrm{g} \mathrm{ml}^{-1}\right)$ & Microfilament inhibitor & $0.59 \pm 0.41^{*}$ & $28 \cdot 4 \pm 16 \cdot 1^{*}$ \\
\hline Vincristin $\left(5 \mu \mathrm{g} \mathrm{ml}^{-1}\right)$ & Microtubule inhibitor & $123 \cdot 2 \pm 14 \cdot 7$ & $62 \cdot 4 \pm 5 \cdot 1^{*}$ \\
\hline
\end{tabular}

randomly in the monolayers and increased in size over time.

\section{Morphological changes induced in EPC cells by Vibrio species seen using phase-contrast microscopy}

Four vibrios were chosen as representatives of cytopathic and non-cytopathic groups for detailed study. EPC monolayers inoculated with $V$. damselae ATCC 33539 , and $V$. anguillarum 811218-5W and G/Virus/ 5 (3) (cytopathic group) underwent different morphological changes whereas those inoculated with $V$. anguillarum S2/5/93(2) (non-cytopathic group) did not show any changes by $8 \mathrm{~h}$ after inoculation (Fig. 1e). These three cytopathic strains were chosen for their different effects induced in EPC monolayers. Uninfected EPC cells adhered tightly to their neighbours in the monolayer (Fig. 1a). EPC cells infected with strain $V$. anguillarum 811218-5W (invasive group I) underwent a series of morphological changes which could be divided into three stages. At the end of stage I $(35.0 \pm 3.0 \mathrm{~min}$ after infection, $n=3$ ), the cells had become slightly detached from one another, lost their smooth appearance and appeared darker (Fig. 1b). At the end of stage II $(44.7 \pm 2.5 \mathrm{~min}$ after infection, $n=3)$, the space between cells had widened and only $50 \%$ of the cells remained attached to the tissue culture plate (Fig. 1c). The cells had retracted and were connected by elongated filaments. At the end of stage III $(91.7 \pm 2.9 \mathrm{~min}$ after infection, $n=3$ ), the cells had become rounded and the filamentous connections were lost (Fig. 1d).

Morphological changes in EPC cells infected with $V$. anguillarum $\mathrm{G} /$ Virus $/ 5(3)$ (invasive group II) could also be divided into three stages. The appearance of the cells at the end of stage III of infection by this strain was similar to that described for strain $811218-5 \mathrm{~W}$. However, this strain took a longer time to reach the end of stage III $(125.0 \pm 5.0 \mathrm{~min}$ after infection, $n=3)$. In addition, rounded and transparent cells appeared in the initial stage (stage I, $87 \cdot 7 \pm 6 \cdot 6 \mathrm{~min}$ after infection, $n=3$ ) (Fig. 1f) and the abundance of such transparent cells increased gradually over time (Fig. 1g for stage II, $108 \cdot 0 \pm 14 \cdot 4$ min after infection, $n=3$ ).

EPC cells infected with $V$. damselae ATCC 33539 (cytotoxic group) detached from one another and appeared slightly retracted. Some EPC cells at randomly distributed sites retracted more than others to form gaps (Fig. 1h). With time the gaps between EPC cells increased in size. There were no filaments between neighbouring cells. Finally, the remaining cells that bordered the holes became rounded and detached from the wells.

\section{Confocal study of infected EPC cells}

Vibrios were labelled with Live/Dead BacLight viability fluorescent stain to reveal their fates inside the cells. EPC cells inoculated with $V$. anguillarum S2/5/93(2) (noncytopathic strain) did not show any morphological changes (Fig. 2a). They appeared normal and the cellular structures were intact. Bacteria were found outside, but not inside the EPC cells (Fig. 2b). EPC cells infected with $V$. damselae ATCC 33539 became rounded and elongated. Bacteria were seen moving freely outside EPC cells (Fig. 2c). On the other hand, EPC cells infected with $V$. anguillarum 811218-5W and G/Virus/5(3) showed distinctive morphological changes (Fig. $2 \mathrm{~d}-\mathrm{g}$ ). In the last stage the cells became rounded and transparent. The cell nuclei and other organelles had disintegrated. Bacteria were seen moving freely inside the cells. To confirm that the bacteria were inside the EPC cells, optical sectioning was carried out at serial $2 \mu \mathrm{m}$ intervals along the $z$ axis (Fig. $2 \mathrm{~d}-\mathrm{g}$ ). Aggregates of $V$. anguillarum $811218-5 \mathrm{~W}$ and G/Virus/5(3) were located in the mid-region (middle plane) of the infected cells (Fig. 2e, g, respectively). 

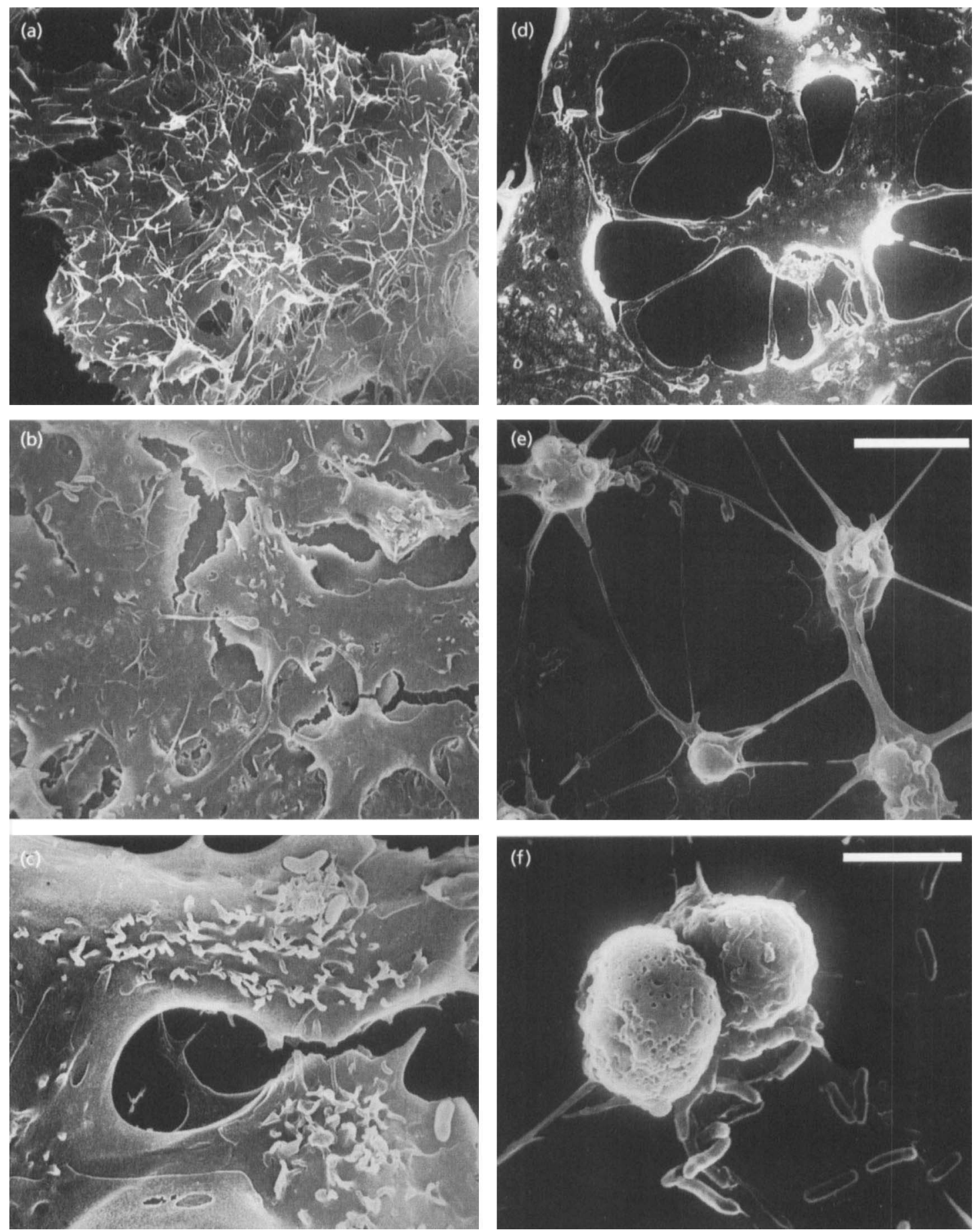

Fig. 4. Scanning electron micrographs of EPC monolayers infected with $V$. anguillarum 811218-5W. (a) Uninfected EPC cells. (b) Before the end of stage I, microvilli had receded and the cytoplasm of the cells had condensed. (c) Receded microvilli in a highly magnified view. (d) At the end of stage $I$, the cells became detached from one another and retracted. (e) At the end of stage II, the general morphology changed drastically. The cells were retracted such that they were held together by thin elongated strands of cytoplasm. (f) At the end of stage III, the cells had retracted and condensed into ball-like structures with rough-looking surfaces. Bar in (e) (also applies to a, b, d), $15 \mu \mathrm{m}$; bar in (f) (also applies to c) $5 \mu \mathrm{m}$. 

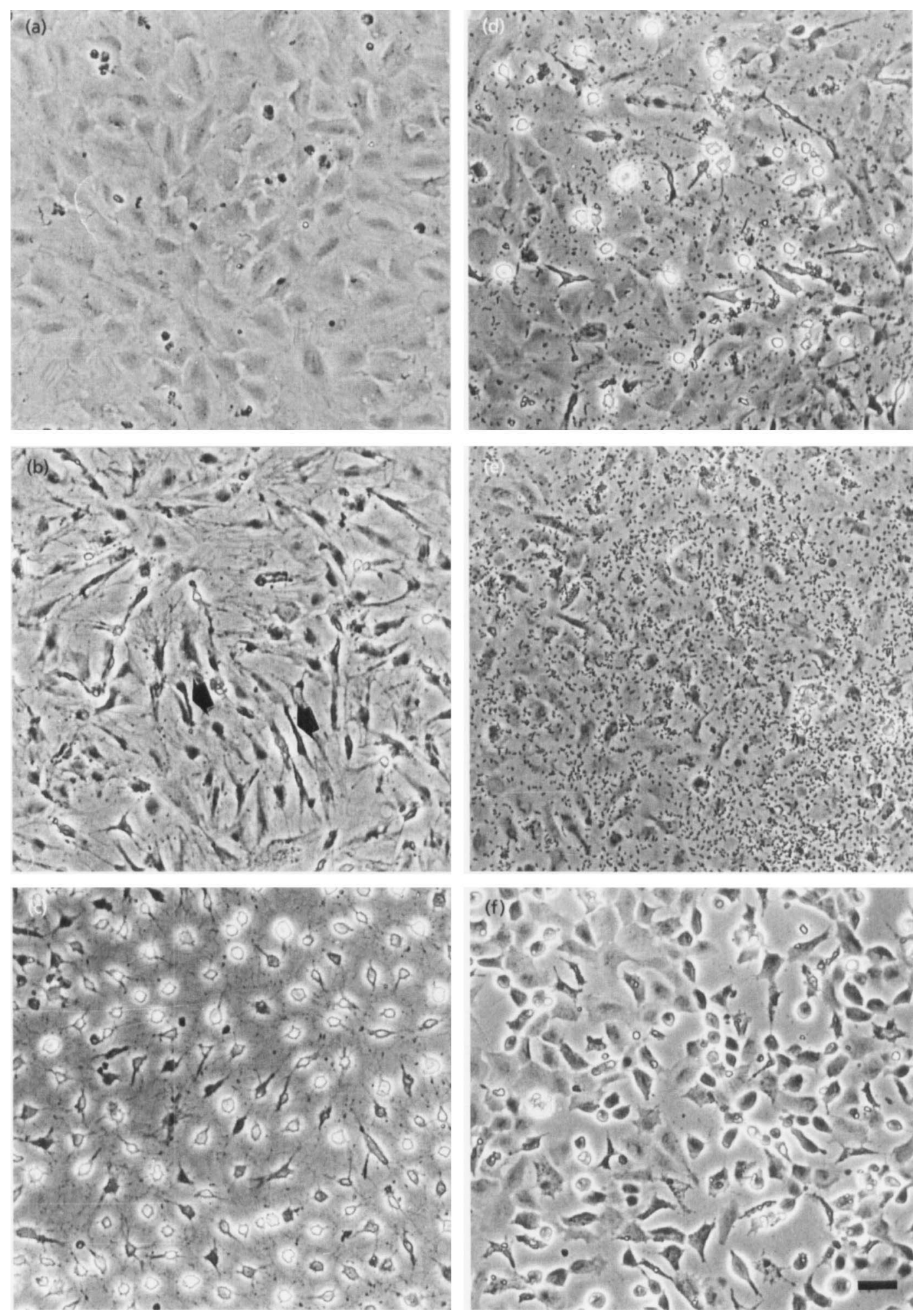

Fig. 5. Phase-contrast micrographs of GF cells infected with $V$. anguillarum $811218-5 \mathrm{~W}$ (b, 38 min after infection and $c$, $60 \mathrm{~min}$ after infection); GNirus/5(3) (d, $80 \mathrm{~min}$ after infection); S2/5/93(2) (e, $120 \mathrm{~min}$ after infection); and GF cells incubated for $25 \mathrm{~min}$ with ECP produced by V. damselae ATCC 33539 (f). (a) Uninoculated GF cells. (b, d) Stage I of infection. For group I, inoculated GF cells retracted and formed pointed edges or ends which connected neighbouring cells (indicated by arrows in b), whilst for group II, about $50 \%$ of the field was filled with rounded and light-coloured cells (d). (c) Stage II of infection, where the entire monolayers were filled with rounded and light-coloured cells. Bar, $25 \mu \mathrm{m}$. 


\section{Adherence to and invasion of EPC cells by Vibrio species}

V. anguillarum 811218-5W and G/Virus/5(3) showed significantly greater adherence $(P<0.05)$ to EPC cells than the other strains tested at different concentrations of bacteria (Table 2). In addition, the invasiveness of these two strains was significantly higher $(P<0.05)$ compared to that of the other strains at various bacterial concentrations. These results, together with the findings revealed by confocal microscopy, suggested that $V$. anguillarum 811218-5W and G/Virus/5(3) could be considered invasive strains. Furthermore, $V$. anguillarum 811218-5W adhered strongly to the EPC cells and to the surface of plastic coverslips, with at least 10 -fold more bacteria found on the plastic coverslip compared to other strains. In addition, V. anguillarum $811218-5 \mathrm{~W}$ adhered substantially more to EPC cells than $V$. anguillarum $\mathrm{G} /$ Virus/5(3) (Table 2). Using scanning electron microscopy, appendages were found around the bacteria and joined to form a network on the coverslips as shown in Fig. 3(a). The rest of the vibrios did not form appendages and very few bacteria were observed on the coverslips (Fig. $3 \mathrm{~b}$ ).

\section{Effects of inhibitors on internalization of Vibrio species in EPC}

Bacterial uptake usually involves the exploitation of host cell functions to facilitate invasion. Different classes of inhibitors (Table 3) were used to better understand the roles of the cellular cytoskeleton and signal transduction pathways in the internalization of two invasive strains of $V$. anguillarum in EPC cells. Internalization of $V$. anguillarum $\mathrm{G} /$ Virus $/ 5(3)$ was more sensitive to inhibition by a variety of inhibitors than internalization of $V$. anguillarum 811218-5W. We found that the internalization of $V$. anguillarum 811218-5W and G/Virus/5(3) was extremely sensitive to cytochalasin D, a specific blocker of actin polymerization. Inhibition of internalization by cytochalasin $\mathrm{D}$ was observed at concentrations as low as $0 \cdot 1 \mu \mathrm{g} \mathrm{ml}^{-1}$. Therefore, it is most likely that these two strains enter EPC cells by triggering rearrangements of the actin microfilament system. Vincristin, an inhibitor of microtubulin, significantly reduced internalization of $V$. anguillarum G/Virus/5(3), but not that of V. anguillarum 811218$5 \mathrm{~W}$. Genistein, a specific tyrosine kinase inhibitor, significantly inhibited internalization of $V$. anguillarum $\mathrm{G} /$ Virus/5(3) but not that of $V$. anguillarum 811218$5 \mathrm{~W}$. In addition BAPTA/AM, a membrane permeant intracellular $\mathrm{Ca}^{2+}$ chelator, significantly inhibited $V$. anguillarum $\mathrm{G} /$ Virus/5(3) internalization whilst $\mathrm{Ca}^{2+}$ free MEM did not. On the other hand, staurosporine, a non-selective protein kinase $\mathrm{C}$ inhibitor, significantly accelerated internalization of V. anguillarum G/Virus/ $5(3)$ and $811218-5 \mathrm{~W}$, whilst calphostin C, a highly specific protein kinase $\mathrm{C}$ inhibitor, failed to block the internalization of either $V$. anguillarum strain. This finding indicates that staurosporine promoted $V$. anguillarum internalization through mechanisms other than protein kinase C inhibition. PD098059, a mitogen- activated protein kinase kinase inhibitor, did not affect internalization of either strain. None of the inhibitors interfered with bacterial viability or the viability of EPC cells (data not shown).

\section{Scanning electron microscopic analysis}

For the EPC monolayer that was infected with the noncytopathic strain $V$. anguillarum S2/5/93(2), cell morphology was similar to that of the control group. The morphology of the monolayer had not changed $8 \mathrm{~h}$ after inoculation (Fig. 3c). For the EPC monolayer inoculated with $V$. damselae ATCC 33539, the edges of the cells folded upwards and appeared to be in the process of detaching $60 \mathrm{~min}$ after inoculation (Fig. 3d). The monolayer also appeared to be loosely attached to the surface. Later after inoculation $(3 \mathrm{~h})$, there was greater folding of the cells and the monolayer appeared to be more loosely attached to the neighbouring cells and also to the surface of the coverslip (Fig. 3e). Fig. 3(f) shows the morphological changes on the surface of EPC cells inoculated with $V$. anguillarum G/Virus/5(3) $90 \mathrm{~min}$ after infection. Mixed changes in surface morphology in EPC cells were observed even at stage I and this correlated with observations made using phase-contrast microscopy (Fig. 1f). Morphological changes, such as elongated EPC cells connected by thin strands of cytoplasm and rounded EPC cells, were observed.

Uninoculated EPC cells had many microvilli on their surface and the cell morphology was as shown in Fig. 4(a). At $20 \mathrm{~min}$ after inoculation with $V$. anguillarum 811218-5W, microvilli had greatly receded (Fig. 4b, c). Inoculated EPC cells were condensed and retracted, and the cell morphology had changed substantially compared to uninoculated cells. At the end of stage I, the cells had become detached from each other (Fig. 4d). At the end of stage II, the cytoplasm of the cells had condensed and the cells were retracted to the point that they were only held to one another by elongated filaments (Fig. 4e). At the end of stage III, the cytoplasm of the cells had completely retracted and condensed into ball-like structures with a rough surface (Fig. 4f). The elongated filaments holding the cells together had disappeared.

\section{Interactions of GF cells with Vibrio species}

GF cells were used as a second fish epithelial cell line and were infected with 24 Vibrio strains separately. The changes in morphology of the infected GF cells and the grouping of vibrios based on cytopathic changes were similar to those of the infected EPC cells as shown in Table 1. Control GF cells were closely apposed and had a regular shape (Fig. 5a). GF cells infected with strains classified under invasive groups I (represented by $V$. anguillarum $811218-5 \mathrm{~W}$ ) and II [represented by $V$. anguillarum G/Virus/5(3)] underwent two stages of morphological changes for each group. At the end of stage I, cells inoculated with $V$. anguillarum $811218-5 \mathrm{~W}$ $(39.0 \pm 1.0 \mathrm{~min}$ after infection, $n=5)$ became darkcoloured and elongated (Fig. 5 b). The retracted GF cells 

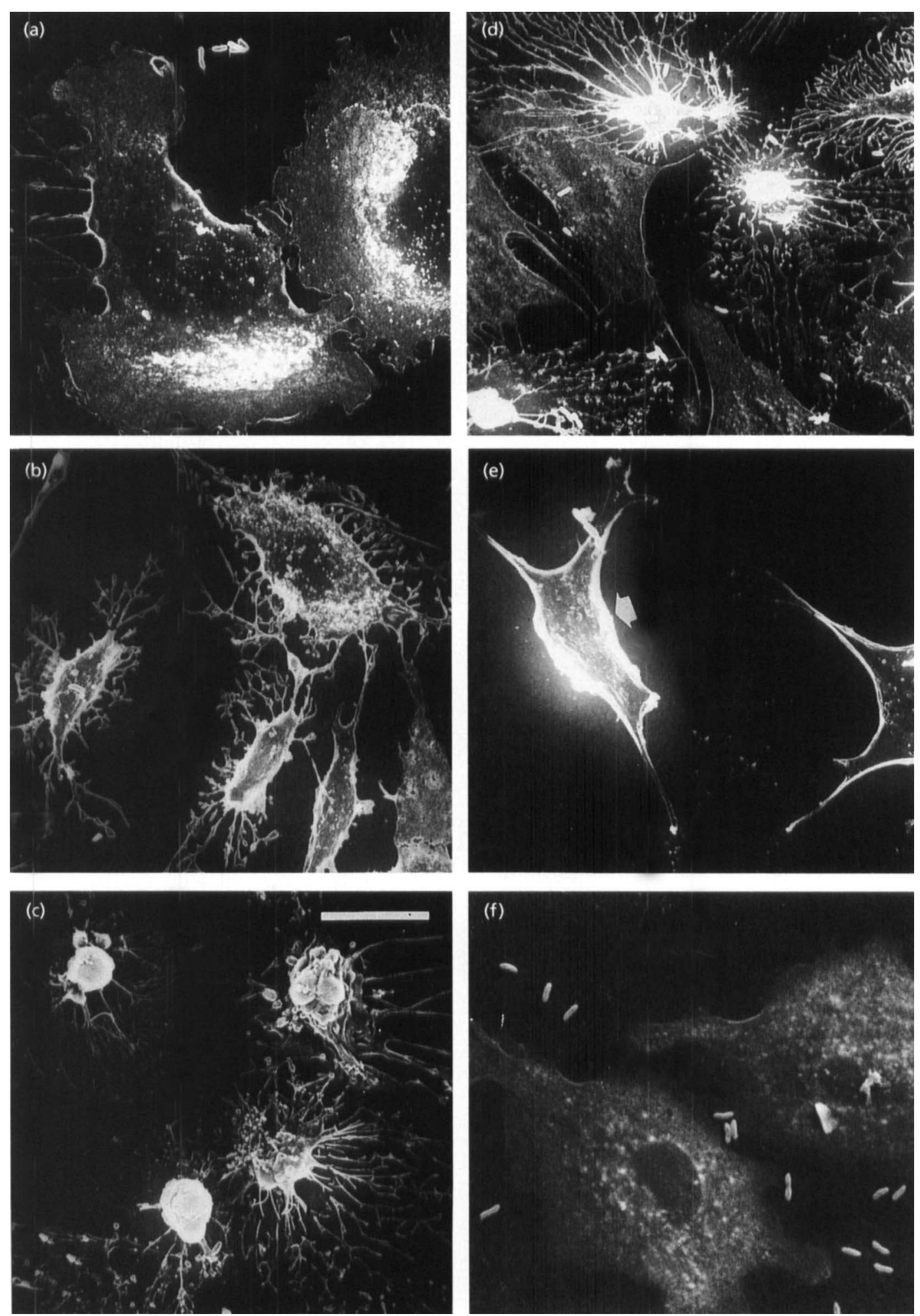

Fig. 6. Scanning electron micrographs of GF cells infected with $V$. anguillarum 811218-5W (a-c), G/Virus/5(3) (d), V. damselae ATCC 33539 (e) and V. anguillarum S2/5/93(2) (f). (a) Sides of the GF cells losing anchorage on the coverslip, just before the GF cells entered stage I. (b) Stage I, showing retracted and elongated GF cells with strands of cytoplasmic leftovers. (c) Stage II, where the GF cells had rounded and had extensive cytoplasmic leftovers. (d) Stage I of infection showing some GF cells that were still anchored to the coverslip, with others that had retracted and become elongated and had a slightly rough surface. Some cells had become rounded with extensive cytoplasmic filaments. (e) GF cells that had become rounded (indicated by arrows). ( $f$ ) GF cells with all sides anchored to the coverslip and with no cytopathic changes. Bar, $15 \mu \mathrm{m}$. 
formed pointed ends or edges which connected neighbouring cells. At the end of stage II $(60 \cdot 3 \pm 2 \cdot 8 \mathrm{~min}$ after infection, $n=5$ ), the GF cells became rounded and lightcoloured (Fig. 5c). In GF cells inoculated with $V$. anguillarum $\mathrm{G} /$ Virus $/ 5(3)$, some areas of the monolayer became dark-coloured and elongated and others rounded and light-coloured. At the end of stage I $(77.7 \pm 3.6 \mathrm{~min}$ after inoculation, $n=5)$, about $50 \%$ of the GF monolayer was filled with rounded and lightcoloured cells (Fig. 5d). The entire monolayer consisted of round and light-coloured cells at the end of stage II $(111.7 \pm 5.7 \mathrm{~min}$ after infection, $n=5)$ (data not shown). No significant morphological changes were observed in GF cells inoculated with non-cytopathic Vibrio strains [represented by $V$. anguillarum S2/5/93(2)] even after incubation overnight (Fig. 5e). V. damselae ATCC 33539 , or its ECP extract alone, induced similar cytotoxic effects on GF monolayers (Fig. 5f).

Scanning electron microscopy revealed the surface morphology of the GF cells. Fig. 6 shows the various stages of morphological changes in GF cells infected with $V$. anguillarum 811218-5W. In Fig. 6(a), $35 \mathrm{~min}$ after bacterial infection (before stage I), the GF cells had lost part of their anchorage to the coverslip and where that occurred, thin strands of cytoplasm connecting the retracted cell to the original periphery of the cell were observed. Fig. 6(b) shows stage I of the morphological changes seen under phase-contrast microscopy in Fig. 5 (b). The GF cells had lost most of their anchorage on the coverslip, except at some points, to give a spindleshaped appearance. Fig. 6(c) shows stage II of the morphological changes seen under phase-contrast microscopy in Fig. 5(c), in which the GF cells had become rounded, with extensive strands of cytoplasmic filaments. Finally, the infected GF cells became completely rounded and lost all anchorage on the coverslip, to give a slightly rough-surfaced spherical structure (data not shown). Fig. 6(d) shows the surface morphological changes of GF cells infected with $V$. anguillarum G/Virus/5(3) 80 min after inoculation (stage I). Mixed changes in surface morphology were observed and this corresponded with observations under phase-contrast microscopy (Fig. 5d). Morphological changes, such as the loss of anchorage, elongation with surface roughening and rounding up with extensive cytoplasmic filaments, were observed. GF cells inoculated with $V$. damselae ATCC 33539 also showed surface morphological changes, as shown in Fig. 6(e). Sixty minutes after inoculation, the cells lost part of their anchorage on the coverslip and the edges of the cells rolled up. The non-cytopathic strain $V$. anguillarum S2/5/93(2) did not induce any surface changes in the GF cells and the cells remained tightly anchored to the coverslip, as shown in Fig. 6(f).

\section{Effect of ECP of Vibrio strains}

ECP are key aspects of the pathogenicity of Vibrio species, and therefore the effects of ECP on EPC and GF cells were studied. ECP obtained either from BHISMA or from MEM containing EPC or GF cells inoculated with bacteria were isolated and their effects on the morphology of EPC or GF cells were studied. The results showed that ECP from the invasive groups grown on BHISMA induced morphological changes in the fish cell monolayers only when produced by $5 \times 10^{7}$ bacteria, a number 100 -fold greater than when added to the monolayers as bacterial cells. ECP produced by $5 \times 10^{5}$ or $5 \times 10^{6}$ bacteria had no effects. However, ECP produced by $V$. damselae ATCC 33539 on BHISMA caused significant morphological changes in the monolayer regardless of the ECP concentration. The changes caused by ECP were identical to those caused by inoculation of $V$. damselae ATCC 33539 onto cell cultures (Fig. 5f). Of the Vibrio strains tested, only ECP produced by $V$. damselae ATCC 33539 in MEM containing fish tissue cells caused morphological changes in the monolayers (data not shown). The ECP produced either on BHISMA plates or in MEM by the non-cytopathic strain did not have any effect on the host cell monolayers (data not shown). Thus, $V$. damselae ATCC 33539 may be classified as a cytotoxic strain, unlike $V$. anguillarum 811218-5W and G/Virus/5(3), which induced morphological changes following contact with fish cells.

\section{DISCUSSION}

The interactions between twenty-four Vibrio strains isolated from diseased fish and two fish epithelial cell lines were studied. EPC was used as a freshwater fish tissue culture model and GF cells as a marine fish tissue culture model. Tissue culture cells, especially epithelial cells, have played a crucial role in investigating bacterial-host interactions because cultured cells are easy to work with, can be maintained under controlled conditions and may be relevant to the diseases under study (Quinn et al., 1997). Our results suggest that cytopathology induced by vibrios in both EPC and GF cells is an indicator of Vibrio virulence (Table 1). Based on morphological changes in cultured fish cells, Vibrio strains can be classified as cytopathic (invasive group I, invasive group II, cytotoxic) or non-cytopathic. Four Vibrio strains were chosen for detailed study ( $V$. anguillarum 811218-5W, invasive group I; G/Virus/ $5(3)$, invasive group II; S2/5/93(2), non-cytopathic; and $V$.damselae ATCC 33539 , cytotoxic). All the cytopathic strains were pathogenic for blue gourami with $\mathrm{LD}_{50}$ values less than $10^{6}$, except for $V$. anguillarum 811218 $5 \mathrm{~W}$ (Table 1). V. anguillarum 811218-5W was chosen for comparison so that the two invasive and the noncytopathic strains belonged to the same species. For the cytotoxic group, V. damselae ATCC 33539 was chosen due to the limited choices in this group.

For the non-cytopathic strains, microscopic studies showed that they did not induce any morphological changes in fish cell monolayers (Figs 1e, 2a, 3c, 5e, 6f). In addition, adherence and invasion assays demonstrated that they were unable to adhere to or invade EPC cells (Table 2). The low values observed were probably the background level in our assays. Vibrio-derived exo- 
enzymes, such as haemolysins and exotoxins, have been reported to be cytotoxic for human and fish cell lines and highly lethal for fish and some species of animals (Toranzo \& Barja, 1993). We found that only ECP secreted from $V$. damselae ATCC 33539 caused cytotoxic changes in EPC cells similar to those produced by the bacteria themselves (data not shown). Since $V$. damselae ATCC 33539 did not adhere to and invade EPC cells, our findings suggest that this strain causes morphological changes in EPC cells only by secreting ECP.

Bacterial adherence to host cells is often an essential step to initiate infection because it localizes pathogens to appropriate target tissues. Adhesion to host cells may result in internalization, either by phagocytosis or by endocytosis induced by the bacteria (invasion). In the present study, V. anguillarum $811218-5 \mathrm{~W}$ and G/Virus/ 5(3) were found to adhere to EPC cells before their internalization (Table 2). In particular, using scanning electron microscopy, V. anguillarum $811218-5 \mathrm{~W}$ was found to be able to adhere non-specifically. When there were no EPC cells on the coverslip, this strain of bacteria was still able to adhere to the coverslip plastic (Fig. 3a). On the other hand, $V$. anguillarum G/Virus/5(3) appeared to require interaction with some components of the host cells, because its adherence was apparent only in the presence of EPC cells. From optical sectioning by confocal microscopy, the ability of these two strains to enter and survive inside EPC cells was confirmed (Fig. 2e, g).

Microfilaments are polymerized filaments of actin which participate in many active cell processes, including cell movement, membrane ruffling and phagocytosis. Microtubules are filaments consisting of polymerized tubulin, forming an extensive network in the cytoplasm and participating in intracellular organelle movement. Microfilaments and/or microtubules have previously been found to be involved in internalization (Rosenshine \& Finlay, 1993; Finlay \& Cossart, 1997; Finlay \& Falkow, 1997) by species such as $A$. bydrophila (Tan $e t$ al., 1998), Salmonella species (Finlay et al., 1991) and Vibrio hollisae (Miliotis et al., 1995). Cytochalasin D is considered a specific and potent inhibitor of actin polymerization, thereby blocking microfilament function, while vincristin can depolymerize microtubules, thus allowing determination of the role of microtubules in bacterial invasion (Rosenshine et al., 1994). Our invasion assays showed that cytochalasin D significantly inhibited entry of $V$. anguillarum 811218-5W and G/Virus/5(3) into EPC cells, whereas vincristin specifically blocked the invasion of $V$. anguillarum $G /$ Virus/ 5(3) (Table 3). These findings indicate that rearrangements of the actin microfilaments are essential for internalization of the two invasive groups of Vibrio. In contrast, microtubule polymerization seems to be involved in the internalization of only $V$. anguillarum G/Virus/5(3).

In addition to recruitment of host cytoskeletal elements, there is increasing evidence for the induction of host cell signalling pathways by bacteria. Invasive bacteria are able to exploit the host cell's existing signalling pathways, including activation of protein tyrosine kinases and of phospholipase $C$, leading to increased intracellular $\mathrm{Ca}^{2+}$ levels and protein kinase $\mathrm{C}$ activity, to stimulate their uptake activity. In the present study, genistein, a specific inhibitor of protein tyrosine kinase with negligible effect on the activity of other serine and threonine kinases (Akiyama et al., 1987), was found to inhibit the internalization of $V$. anguillarum G/Virus/ $5(3)$. This finding suggests that internalization of $V$. anguillarum $\mathrm{G} /$ Virus $/ 5(3)$ involves tyrosine kinase activation. On the other hand, staurosporine, a relatively non-specific protein kinase $\mathrm{C}$ inhibitor (Tamaoki et al., 1986), substantially accelerated internalization of both invasive strains. In contrast, calphostin $\mathrm{C}$, a specific inhibitor of protein kinase $\mathrm{C}$ by interacting with the protein regulatory domain (Kobayashi et al., 1989), had no effect on bacterial internalization. These data indicate that protein kinase $\mathrm{C}$ might not be directly involved in bacterial internalization, and the accelaration of invasion of $V$. anguillarum $811218-5 \mathrm{~W}$ and G/Virus/5(3) by staurosporine might be associated with some signalling pathways other than protein kinase $\mathrm{C}$. Recently, it has been shown in PC12 cells that staurosporine enhanced tyrosine phosphorylation of certain proteins (Rasouly \& Lazarovici, 1994). If this is the case in EPC cells, then activation of tyrosine kinases enhances the invasion of Vibrio and inhibition of tyrosine kinases with genistein blocks the internalization process.

BAPTA/AM, a membrane permeant intracellular calcium chelator (Weiss \& Insel, 1991), significantly decreased the invasion of $V$. anguillarum G/Virus/5(3), but not $V$. anguillarum $811218-5 \mathrm{~W}$. It has been shown that enteropathogenic E. coli (EPEC) and Salmonella typhimurium increase intracellular calcium levels in host cells (Baldwin et al., 1991; Ginocchio et al., 1992) and chelation of intracellular calcium blocked invasion by $S$. typhimurium and delayed the death of EPECinfected cells (Ruschkowski et al., 1992; Baldwin et al., 1993). It is thought that these bacteria may stimulate phospholipase $\mathrm{C}$ activity in host cells, resulting in the formation of inositol 1,4,5-triphosphate $\left(\mathrm{IP}_{3}\right)$ and diacylglycerol. $\mathrm{IP}_{3}$ then triggers release of $\mathrm{Ca}^{2+}$ from intracellular stores, generating an increase in intracellular calcium that appears to be an important signal in the infection process. Intracellular calcium levels can affect protein-protein interactions and cause alterations in actin filament structure through proteins such as villin and gelsolin (Korn, 1982). Invasion of EPC cells by both Vibrio strains was not affected by $\mathrm{Ca}^{2+}$-free MEM indicating that extracellular $\mathrm{Ca}^{2+}$ influx did not play a role in bacterial internalization. Taken together, our data suggest that internalization of $V$. anguillarum $\mathrm{G} /$ Virus/5(3) into EPC cells probably involved increases in cytoplasmic $\mathrm{Ca}^{2+}$ from internal $\mathrm{Ca}^{2+}$ stores.

Genistein, staurosporine, BAPTA/AM, cytochalasin D and vincristin may affect internalization by other nonspecific mechanisms, including diminished viability or some effect on bacterial function that impairs their ability to induce internalization. Moreover, the drugs 
may affect the normal function of EPC cells. Each of these possibilities was examined and the data showed that these inhibitors did not affect the bacteria and EPC cells in these non-specific ways. Thus, these inhibitors acted primarily on processes required for bacterial internalization.

Our results show that $V$. anguillarum $811218-5 \mathrm{~W}$ and $\mathrm{G} /$ Virus/5(3) have the capacity to enter eukaryotic cells. It is likely that they adhere to the host cell surface before internalization. At present, it is not clear whether they adhere to host cells by pili or non-pilus adhesins. These two strains trigger an uptake mechanism into fish EPC cells that clearly depends on microfilament rearrangements. Our findings also indicate that these two Vibrio strains have some differences in their method of entering host cells. In contrast to V. anguillarum 811218-5W, the internalization of G/Virus/5(3) into EPC cells involves activation of tyrosine kinase and increases in intracellular $\mathrm{Ca}^{2+}$. Identification of the bacterial and cellular counterparts involved in these processes would help to identify the invasion strategies used by these pathogens and could contribute to our understanding of the pathogenesis of Vibrio infections.

\section{ACKNOWLEDGEMENTS}

The authors are grateful to the National University of Singapore (K.Y.L.) and National Medical Research Council of Singapore (W.S.F.W.) for providing research grants for this work. We would like to thank Dr P. Tang for helpful constructive criticism. We also wish to thank Drs T. T. Ngiam and $\mathrm{H}$. Loh at the Primary Production Department of Singapore, and Dr Y. L. Song, National Taiwan University of Republic of China for providing us with the Vibrio isolates. We are grateful to $\mathrm{Mr} \mathrm{H}$. K. Yip for taking the photographs and Ms G. L. Loy for the technical help in electron microscopy.

\section{REFERENCES}

Actis, L. A., Potter, S. A. \& Crossa, J. W. (1985). Iron-regulated outer membrane protein OM2 of Vibrio anguillarum is encoded by virulence plasmid pJMI. J Bacteriol 161, 736-742.

Akiyama, T., Ishida, J., Nakagawa, S., Ogawara, H., Watanabe, S., Itoh, N., Shibuya, M. \& Fukami, Y. (1987). Genistein, a specific inhibitor of tyrosine-specific protein kinases. J Biol Chem 262, 5592-5595.

Austin, B. \& Austin, D. A. (1993). Bacterial Fish Pathogens: Disease on Farmed and Wild Fish, 2nd edn. Chichester: Ellis Horwood.

Baldwin, T. J., Ward, W., Aitken, A., Knutton, S. \& Williams, P. H. (1991). Elevation of intracellular free calcium level in Hep-2 cells infected with enteropathogenic Escherichia coli. Infect Immun 59, 1599-1604.

Baldwin, T. J., Lee, D. M., Knutton, S. \& Williams, P. H. (1993). Calcium-calmodulin dependence of actin accretion and lethality in cultured Hep-2 cells infected with enteropathogenic Escherichia coli. Infect Immun 61, 760-763.

Baudin-Laurencin, F. \& German, E. (1987). Experimental infection of rainbow trout, Salmo gairdneri R., by dipping in suspensions of Vibrio anguillarum, ways of bacterial penetration; influence of temperature and salinity. Aqua 67, 203-205.
Breed, R. S. (1996). Facultatively anaerobic Gram-negative rods. In Bergey's Manual of Determinative Bacteriology, 9th edn, pp. 192, 260-272. Edited by J. G. Holt, N. R. Krieg, P. H. A. Sneath, J. T. Staley \& S. T. Williams. Baltimore: Williams \& Wilkins.

Clem, L. W., Moewus, L. \& Sigel, M. M. (1961). Studies with cells from marine fish in tissue culture. Proc Soc Exp Biol Med 108, $762-766$.

Donnenberg, M. S., Donohue-Rolfe, A. \& Keusch, G. T. (1989). Epithelial cell invasion, an overlooked property of enteropathogenic Escherichia coli (EPEC) associated with the EPEC adherence factor. $J$ Infect Dis 160, 452-459.

Donnenberg, M. S., Donohue-Rolfe, A. \& Keusch, G. T. (1990). A comparison of Hep-2 cell invasion by enteropathogenic and enteroinvasive Escherichia coli. FEMS Microbiol Lett 69, 83-86.

Elsinghorst, E. A. (1994). Measurement of invasion by gentamicin resistance. Methods Enzymol 236, 405-420.

Espelid, S., Mielmel, K. \& Jørgensen, T. (1987). The specificity of Atlantic salmon antibodies made against the fish pathogen Vibrio salmonicida, establishing the surface protein VS-P1 as the dominating antigen. Dev Comp Immunol 11, 529-537.

Finlay, B. B. \& Cossart, P. (1997). Exploitation of mammalian host cell functions by bacterial pathogens. Science 276, 718-725.

Finlay, B. B. \& Falkow, S. (1988). Comparison of the invasion strategies used by Salmonella choleraesuis, Shigella flexneri and Yersinia enterocolitica to enter cultured animal cells: endosome acidification is not required for bacterial invasion or intracellular replication. Biochimie 70, 1089-1099.

Finlay, B. B. \& Falkow, S. (1989). Salmonella as an intracellular parasite. Mol Microbiol 3, 1833-1841.

Finlay, B. B. \& Falkow, S. (1997). Common themes in microbial pathogenicity revisited. Microbiol Mol Biol Rev 61, 136-169.

Finlay, B. B., Ruschkowski, S. \& Dedhar, S. (1991). Cytoskeletal rearrangements accompanying Salmonella entry into epithelial cells. J Cell Sci 99, 283-296.

Finlay, B. B., Leung, K. Y., Rosenshine, I. \& Garcia-del Portillo, F. (1992). Salmonella interactions with the epithelial cell. ASM News 58, 486-489.

Ginocchio, C., Pace, J. \& Galan, J. E. (1992). Identification and molecular characterization of a Salmonella typhimurium gene involved in triggering the internalization of salmonellae into cultured epithelial cells. Proc Natl Acad Sci USA 89, 5976-5980.

Grimes, D. J., Gruber, S. H. \& May, E. B. (1985). Experimental infection of lemonsharks, Negaprion brevirostris (poey), with Vibrio species. J Fish Dis 8, 173-180.

Hjeltnes, B. \& Roberts, R. J. (1993). Vibriosis. In Bacterial Diseases of Fish, pp. 109-121. Edited by V. Inglis, R. J. Roberts \& N. R. Bromage. New York: Halsted Press.

Horne, M. T. \& Baxendale, A. (1983). The adhesion of Vibrio anguillarum to host tissue and its role in pathogenesis. J Fish Dis 6, 461-471.

Kanno, T., Nakai, T. \& Muroga, K. (1989). Mode of transmission of vibriosis among Ayu, Plecoglossus altivelis. J Aquat Anim Health $1,2-6$.

Kobayashi, E., Nakano, H., Morimoto, M. \& Tamaoki, T. (1989). Calphostin C (UCN-1028C), a novel microbial compound, is a highly potent and specific inhibitor of protein kinase C. Biochem Biophys Res Commun 159, 548-553.

Korn, E. D. (1982). Actin polymerization and its regulation by proteins from nonmuscle cells. Physiol Rev 62, 672-737. 
Leung, K. Y. \& Finlay, B. B. (1991). Intracellular replication is essential for the virulence of Salmonella typhimurium. Proc Natl Acad Sci USA 88, 11470-11474.

Leung, K. Y. \& Stevenson, R. M. W. (1988). Characteristics and distribution of extracellular proteases from Aeromonas bydrophila. J Gen Microbiol 134, 151-160.

Leung, K. Y., Yeap, I. V., Lam, T. J. \& Sin, Y. M. (1995). Serum resistance as a good indicator for virulence in Aeromonas bydrophila strains isolated from diseased fish in South-East Asia. J Fish Dis 18, 511-518.

Leung, K. Y., Lim, T. M., Lam, T. J. \& Sin, Y. M. (1996). Morphological changes in carp epithelial cells infected with Aeromonas hydrophila. J Fish Dis 19, 167-174.

Miliotis, M. D., Tall, B. D. \& Gray, R. T. (1995). Adherence to and invasion of tissue culture cells by Vibrio hollisae. Infect Immun 63, 4959-4963.

Miller, V. L., Finlay, B. B. \& Falkow, S. (1988). Factors essential for the penetration of mammalian cells by Yersinia. Curr Top Microbiol Immunol 138, 15-39.

Munn, T. W. (1978). Haemolysin production by Vibrio anguillarum. FEMS Microbiol Lett 3, 265-268.

Norqvist, A., Norrman, B. \& Wolf-Watz, H. (1990). Identification and characterisation of a zinc metalloprotease associated with invasion by the fish pathogen Vibrio anguillarum. Infect Immun 58, 3731-3736.

Olsson, J. C., Joborn, A., Westerdahl, A., Blomberg, L., Kjelleberg, S. \& Conway, P. L. (1996). Is the turbot, Scophthalmus maximus (L.), intestine a portal of entry for the fish pathogen Vibrio anguillarum? J Fish Dis 19, 225-234.

Quinn, F. D., Newman, G. W. \& King, C. H. (1997). In search of virulence factors of human bacterial disease. Trends Microbiol 5 , 20-26.

Rasouly, D. \& Lazarovici, P. (1994). Staurosporine induces tyrosine phosphorylation of a $145 \mathrm{KDa}$ protein but does not activate gp140trk in PC12 cells. Eur J Pharmacol 269, 255-264.

Reed, L. J. \& Muench, H. (1938). A simple way of estimating fifty percent end points. Am J Hyg 27, 493-497.

Rosenshine, I. \& Finlay, B. B. (1993). Exploitation of host signal transduction pathways and cytoskeletal functions by invasive bacteria. Bioessays 15, 17-24.

Rosenshine, I., Ruschkowski, S. \& Finlay, B. B. (1994). Inhibitors of cytoskeletal function and signal transduction to study bacterial invasion. Methods Enzymol 236, 467-476.

Rosenshine, I., Ruschkowski, S., Stein, M., Reinscheid, D. J., Mills, S. D. \& Finlay, B. B. (1996). A pathogenic bacterium triggers epithelial signals to form a functional bacterial receptor that mediates actin pseudopod formation. EMBO J 15, 2613-2624.

Ruschkowski, S., Rosenshine, I. \& Finlay, B. B. (1992). Salmonella typhimurium induces an inositol phosphate flux in infected epithelial cells. FEMS Microbiol Lett 95, 121-126.

Tamaoki, T., Nomoto, H., Takahashi, I., Kato, Y., Morimoto, M. \& Tomita, F. (1986). Staurosporine, a potent inhibitor of phospholipid/Ca $\mathrm{Ca}^{++}$dependent protein kinase. Biochem Biophys Res Commun 135, 397-402.

Tan, E., Low, K. W., Wong, W. S. F. \& Leung, K. Y. (1998). Internalization of Aeromonas hydrophila by fish cells can be inhibited with a tyrosine kinase inhibitor. Microbiology 144, 299-307.

Thune, R. L., Stanley, L. A. \& Cooper, K. (1993). Pathogenesis of Gram-negative bacterial infections in warm water fish. Annu Rev Fish Dis 3, 37-68.

Toranzo, A. E. \& Barja, J. L. (1993). Virulence factors of bacteria pathogenic for coldwater fish. Annu Rev Fish Dis 3, 5-36.

Weiss, B. A. \& Insel, P. A. (1991). Intracellular $\mathrm{Ca}^{2+}$ and protein kinase $C$ interact to regulate $\alpha 1$-adrenergic- and bradykinin receptor-stimulated phospholipase $\mathrm{A} 2$ activation in madin-darby canine kidney cells. J Biol Chem 266, 2126-2133.

Wolf, K. \& Mann, J. A. (1980). Poikilotherm vertebrate cell lines and viruses, a current listing for fishes. In Vitro 16, 168-179.

Wright, A. C., Simpson, L. M., Oliver, J. D. \& Glenn-Morris, J., Jr (1990). Phenotypic evaluation of acapsular transposon mutants of Vibrio anguillarum. Infect Immun 58, 1769-1773.

Yoshida, S. l., Ogawa, M. \& Mizuguchi, Y. (1985). Relation of capsular materials and colony opacity to virulence of Vibrio vulnificus. Infect Immun 47, 446-451.

Received 6 January 1998; revised 28 July 1998; accepted 17 August 1998. 